\title{
The Demand For Tourism: Japanese Visitors In The United States
}

Akinori Tomohara, University of California, Los Angeles, USA

Molly Sherlock, Skidmore College, USA

\begin{abstract}
This paper uses the supply-and-demand framework to explore Japanese citizens' demand for U.S. exported tourism services. The time period chosen analyzes Japanese demand for tourism following Japan's banking crisis and the subsequent changes in the nature of Japan's labor market. Traditionally, the literature has found that real GDP is a significant factor in the demand for tourism services. We find that changes in Japan's real GDP does not appear to explain changes in the Japanese citizens' demand for U.S. tourism services following Japan's 1997 banking crisis. However, the structural changes to Japan's labor market following the banking crisis caused real wages to fall, despite a continued increase in aggregate GDP. We argue that using aggregate measures of income, such as real GDP, is only appropriate when those aggregate measures of income exhibit trends similar to disaggregated measures of income. Other factors of demand, such as the price, the availability of substitutes, and tastes and preferences are shown to operate as economic theory would predict.
\end{abstract}

Keywords: Tourism Demand, Factors of Demand

\section{INTRODUCTION}

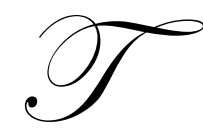

he supply-and-demand model is the cornerstone of modern economic theory. Our daily lives are filled with scenarios that can be explained using the supply-and-demand framework. The supplyand-demand framework predicts, for example, that when the price of a trip to Disneyland increases, individuals purchase fewer trips to Disneyland. Supply-and-demand theory also predicts that when the price of a trip to Disneyland increases, consumers purchase fewer McDonald's meals at Disneyland's on-site McDonalds. ${ }^{1}$ Tickets to Disneyland and meals at the on-site McDonald's are complements - as the price of one increases the demand for the other falls. As the price for meals at the Disneyland McDonald's falls the demand for meals elsewhere may increase. Meals at Disneyland's McDonald's and meals elsewhere are substitutes - as the demand for one good decreases the demand for the other increases. The demand for meals at Disneyland's McDonald's has fallen because the price of being at Disneyland increased. For substitute goods, when the price of one good increases the demand for the substitute increases.

Not only do the prices of related goods affect consumers' purchasing decisions. Income is also a major determinant of demand. For normal goods, when an individual's income increases, the individual purchases more of a good at any price. Higher incomes are likely to lead individuals to purchase more expensive forms of entertainment, such as trips to amusement parks like Disneyland.

Individual's tastes and preferences, information, and government regulations are also factors that determine how much of a good is demanded. It is easy to imagine how attendance at Disney resorts is likely to fluctuate with the popularity of other Disney movies and products, and how these are a reflection of general social trends. Also, if travel agents provide information to potential travelers on Disneyland's products and packages, the number of visitors is likely to increase. Finally, government taxes on rooms and meals can influence the price of vacations to Disneyland, and thereby change demand. 
Formally, the demand for goods and/or services is a function of the price of the good, the prices of related goods, income, and other factors such as tastes and preferences. While the supply-and-demand model is typically used to evaluate the market for goods like cars and commodities, it is equally applicable to the market for services. In this paper we explore the demand for tourism using Japanese tourism in the U.S. as a case study. In doing so, we highlight the importance of examining income in a disaggregated form, and emphasize that GDP may not be an effective proxy for aggregated individual income.

\section{TOURISM DEMAND}

Tourism within the United States can be viewed as an exported service. Foreign countries, therefore, are importing tourist services from the United States. The demand for imports behaves similarly to the demand for other goods. When foreign income increases, greater quantities are demanded. Similarly, when the price of an imported good falls, the quantity demanded increases.

Historically, Japanese visitors and their generous spending patterns have represented an important component of the U.S. tourism industry. The United Kingdom and Japan are the most well represented countries in terms of visitors within the United States. ${ }^{2}$ In terms of spending, however, the importance of Japanese visitors is magnified. In 2006, Japanese tourists spent \$284 million while visiting the city of Los Angeles. This is 1.7 times more than U.K. visitors spent. While Japanese visitors remain an important component of international tourism demand within the U.S., the number of Japanese visitors within the U.S. has been declining. Figure 1 illustrates this trend. Our task here is to employ demand analysis in order to understand why this decline is likely to have occurred.

Figure 1: Japanese Visitors with the United States

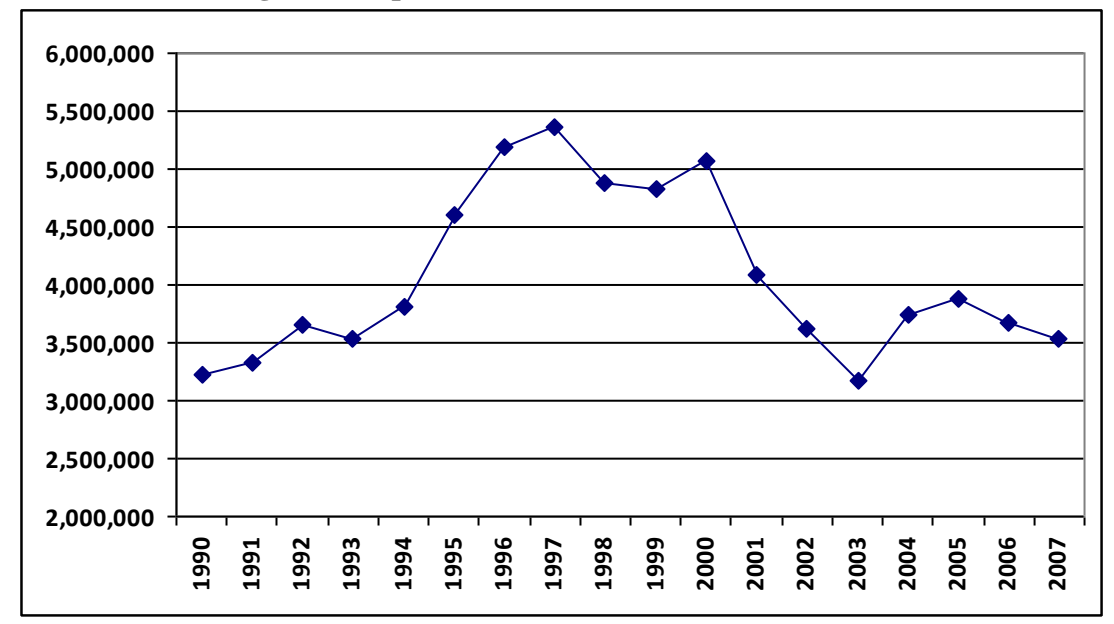

Source: U.S. Department of Commerce ITA Office of Travel \& Tourism Industries

When discussing the tourism decline within the U.S. it is natural to look to the terrorist attacks of September 11, 2001. The number of international visitors to the U.S. declined sharply following $9 / 11$ and has been relatively slow to recover. ${ }^{3}$ Enhanced security following $9 / 11$ made international travel inconvenient. The number of visitors from Japan dropped significantly following 2001 and has hovered around 3.5 million visitors per year since then. An examination of Figure 1 shows that the decline in Japanese visitors to the U.S. began before the events of 9/11. The terrorist attacks of 9/11 likely accelerated the decline in the number of Japanese visitors, but were likely not the sole cause of the decline.

Referring back to the determinants of demand, we are reminded that income is likely to be an important factor in determining Japanese visitors demand for tourism services within the United States. One would expect that a decline in income in Japan would be associated with a decline in the number of visitors to the U.S., and vice versa. Figure 2 plots Japanese real GDP and the number of Japanese visiting the U.S. between 1997 and 2007. Since 1998, 
real GDP in Japan has trended upward. The number of visitors to the U.S. declined in nearly every year during this time period. The literature tends to find that real GDP, a standard measure of aggregate income, is a determinant of tourism demand. ${ }^{4}$ However, it does not appear to be the case that Japanese real GDP was a significant factor in determining the demand for tourism to the United States.

Figure 2: Number of Japanese Visitors and Real GDP

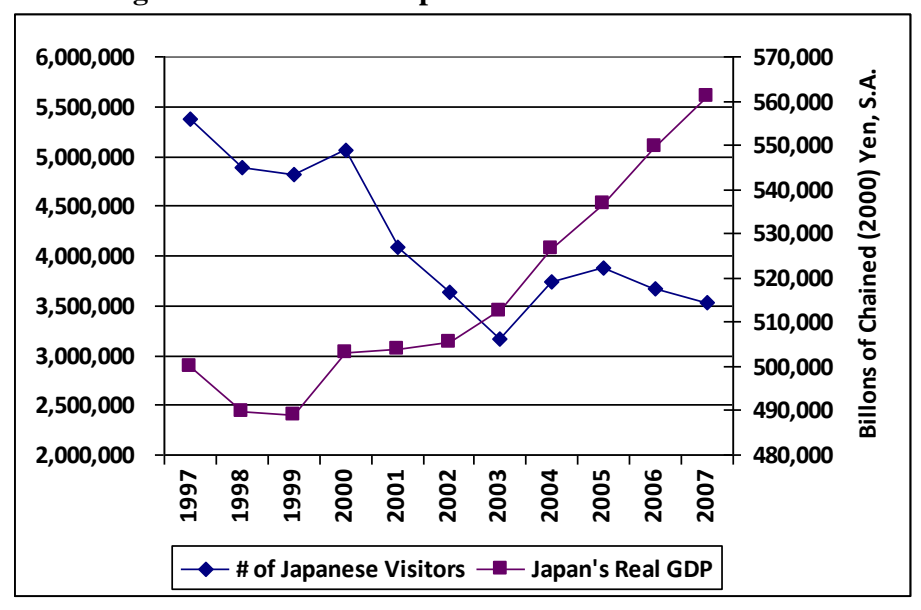

Source: Japanese Cabinet Office

Figure 1 reveals that the number of Japanese tourists visiting the United States started to decline in 1997 even though the Japanese economy had been in a recession since 1991. Japan experienced a banking crisis in 1997. A number of Japanese banks were forced into bankruptcy. Following these bankruptcies, the Japanese economy slumped even further. Labor markets were dramatically impaired. Historically, layoffs have not been common among Japanese companies. Following the banking crisis, Japanese companies began to utilize short-term contract workers, temporary workers, and part-time workers more intensively. These so-called "non-regular staff" allowed companies more flexibility with respect to their employment levels. Prior to 1997, the ratio of non-regular staff to total employees was approximately 20\%. Following the 1997 banking crisis, the ratio of non-regular staff to total employees increased, reaching $34 \%$ in $2002 .^{5}$

Figure 3: Japan's Real Wage Index

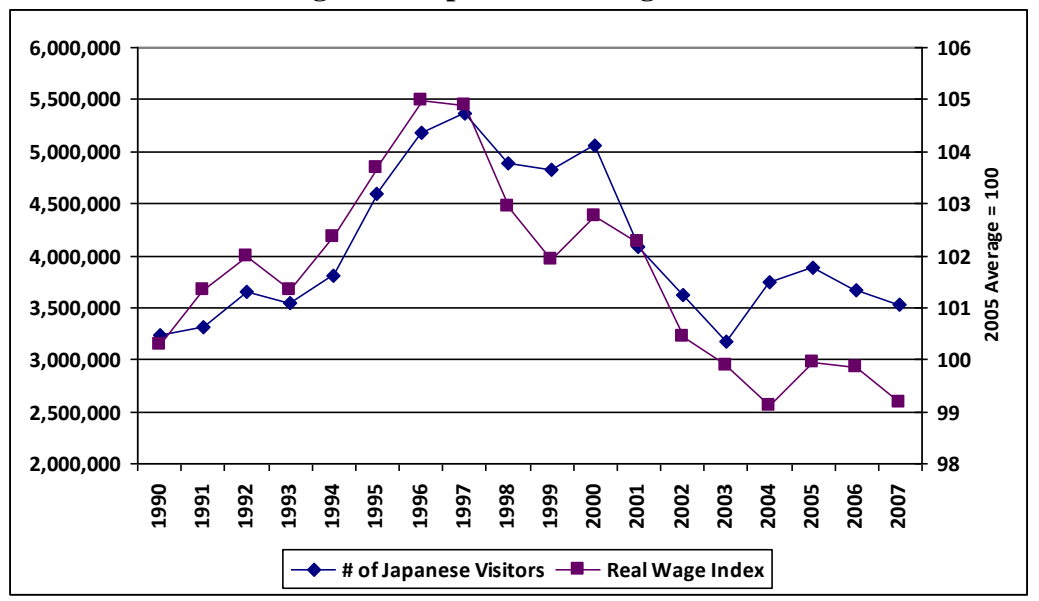

Source: Ministry of Land, Infrastructure, and Transport 
Non-regular staff tend to be paid less than their full-time counterparts. Consequently, the increased utilization of non-regular staff led to a decline in the disposable income of Japanese workers. Figure 3 plots a real wage index along with the number of Japanese visiting the United States. A real wage index provides a better measure of the income of Japanese workers and may provide more insight into the reasons for the decline in the number of Japanese tourists in the United States.

The case of Japanese tourism in the United States highlights the fact that aggregate measures of income, such as GDP, may not be the best measure of income when analyzing the demand for services. Understanding why this is the case relies on understanding how aggregate demand curves are derived. The aggregate demand for Japanese tourism in the U.S. is the sum of each individual Japanese citizen's demand for U.S. exports of tourism services. Since the aggregate demand curve for a service is the sum of individual demand curves, it follows that demand depends on the income of individuals. If the income of individuals is falling, then aggregate demand would be expected to fall. The real wage index suggests that while aggregate GDP was increasing, real wages per worker were falling.

While fewer Japanese citizens were visiting the U.S. following 1997, it does not appear to be the case that Japanese citizens stopped travelling abroad. Figure 4 illustrates the destination of Japanese tourists from 1997 through 2007. It is clear that the number of Japanese tourists visiting the United States and Europe declined throughout the period. However, the number of Japanese tourists visiting China increased relatively steadily throughout the period. As of 2007, Japanese tourists are more likely to visit China than they are to visit the United States. Travel to neighboring countries, such as China, is about half as expensive as travelling to the United States. As the disposable incomes of Japanese citizens declined, Japanese tourists responded by substituting relatively cheap trips to China for trips to the United States. ${ }^{6}$

Figure 4: The Destination of Japanese Tourists

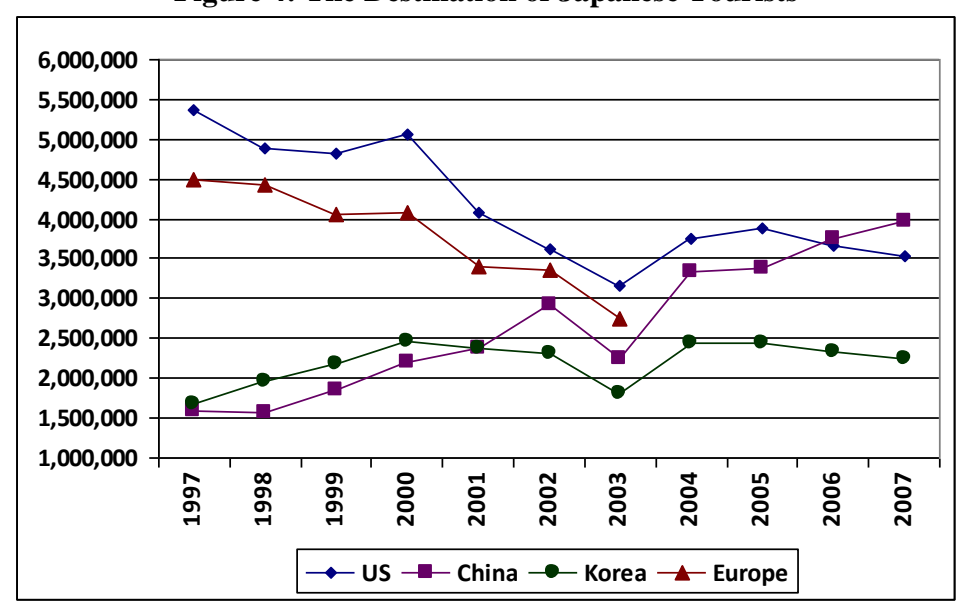

Source: Ministry of Land, Infrastructure, and Transport

A fuller understanding of this substitution requires an analysis of tourism's price. The literature defines the price of tourism as the ratio of the Consumer Price Index (CPI) in the visitor's home country to the CPI in the destination country, adjusted for exchange rates (Durbarry, 2008). Given that tourism prices are difficult to measure directly, the CPI serves as a proxy. Since the CPI is measured in each country's local currency, the exchange rate in each period is used to adjust the measure of prices into consistent units. Figure 5 illustrates the relationship between the number of Japanese visitors in the United States and tourism prices.

Generally, aggregate price levels do appear to explain fluctuations in the number of Japanese visiting the United States. When the price of tourism is increasing, the number of tourists visiting the United States is falling. In both Figure 4 and Figure 52003 appears as an anomoly. The number of Japanese visiting China increased in every year between 1997 and 2007 except for 2003. Also, in 2003, even though the price of tourism in the U.S. was 
falling, the number of Japanese visitors declined. It is likely that concerns surrounding the outbreak of SARS in China and the Iraq war in the United States explain this break in the general trend.

Figure 5: Tourism Prices and Japanese Tourists

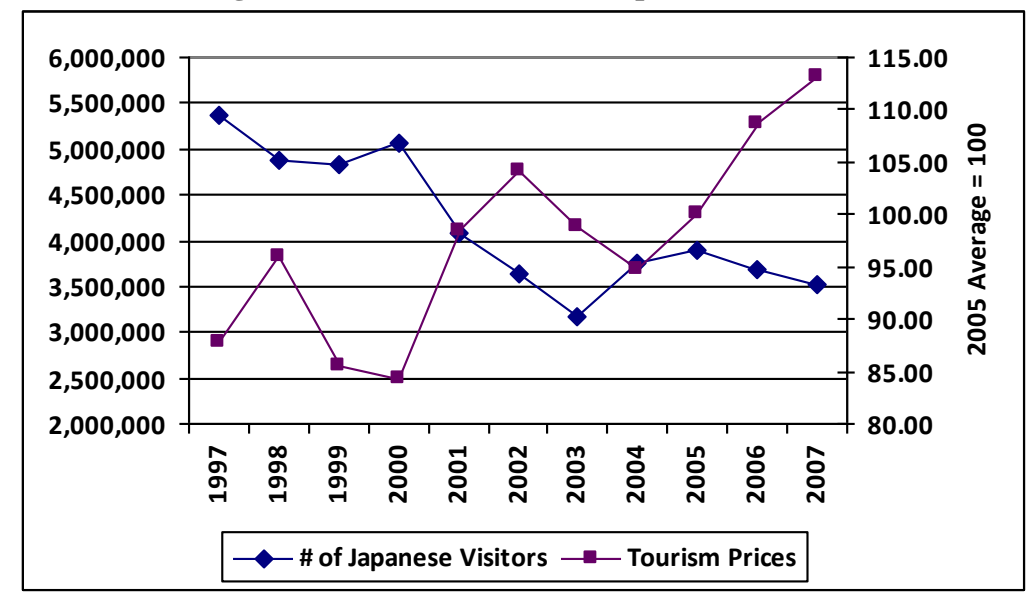

Source: International Monetary Fund International Financial Statistics, U.S. Bureau of Labor Statistics, and the Japanese Ministry of Internal Affairs and Communications

Thus far, our analysis has confirmed that income (when disaggregated) and prices do impact the demand for U.S. tourist services by Japanese visitors. Next, we explore whether income and prices are a determinant of demand for U.S. tourism exports by Chinese visitors. Figure 6 illustrates the relationship between real GDP in China and the number of Chinese choosing to visit the United States.

Figure 6: Number of Chinese Visitors and Real GDP

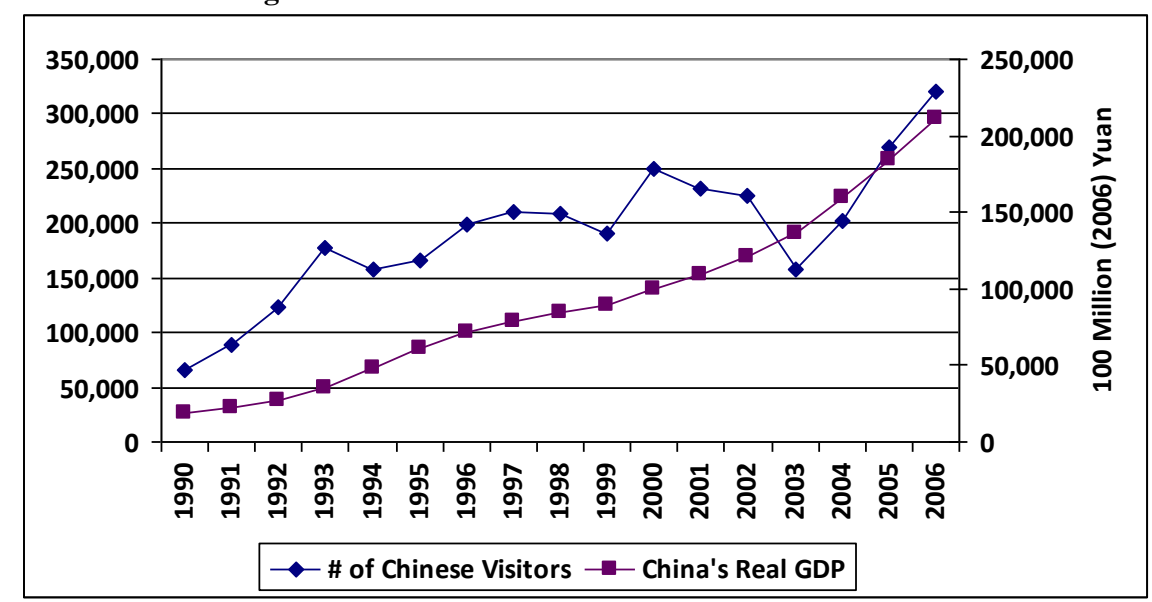

Source: U.S. Department of Commerce ITA Office or Travel \& Tourism Industries and the National Bureau of Statistics of China

Unlike in Japan, real GDP does appear to follow trend with Chinese citizen's demand for exports of U.S. tourism services (again, 2003 is an exception). Real GDP would be expected to explain tourism demand when changes in real GDP reflect changes in disposible income. This suggest that real GDP growth in China likely reflected an overall increase in the purchasing power of Chinese citizens. On the other hand, real GDP growth in Japan occurred while many Japanese citizens were acutally experiencing decreases in their purchasing power. 
Figure 7 illustrates the relationship between the price of tourism faced by Chinese visitors and the number of Chinese visitors in the United States. Tourism prices remained relatively constant between 1990 and 2006 and do not appear to explain much of the variation in Chinese demand for U.S. tourism services. The Chinese Yuan was pegged to the U.S. dollar until 2005 and therefore there was very little fluctuation in the price of tourism.

Figure 7: Tourism Prices and Chinese Tourists

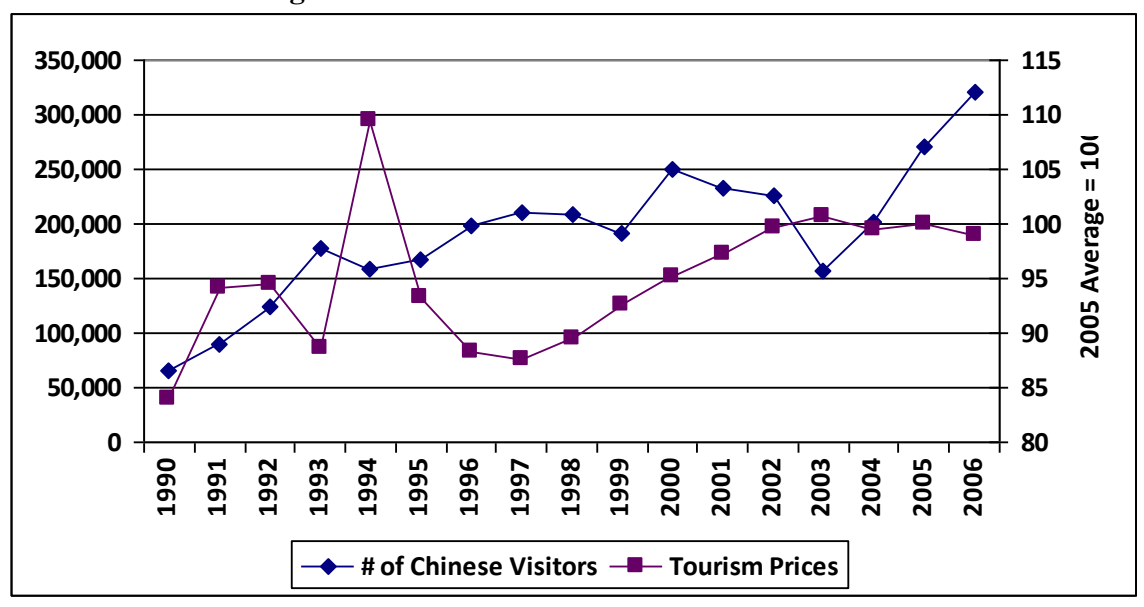

Source: U.S. Department of Commerce ITA Office or Travel \& Tourism Industries and the National Bureau of Statistics of China

\section{CONCLUSION}

Economic theory tells us that the demand for tourism is a function of the income of those travelling, the relative price of tourism, the prices of related goods (other international destinations), and general tastes and preferences for various locations. We have shown here that Japanese tourists demand for travel within the United States is a function of the four aforementioned factors of demand. With respect to income, however, care must be taken to make sure that the measure of income assessed is a measure of Japanese citizen's disposible income. Aggregate income, as measured using Japan's real GDP, does not effectively measure resources available for travel. Japanese citizen's demand for U.S. tourism services appears highly responsive to tourism prices. As China has continued to make travel to China easier, and tensions between China and Japan have continued to diffuse, more and more Japanese citzen's appear to have substituted travel to China for travel to the United States.

\section{AUTHOR INFORMATION}

Akinori Tomohara received his Ph.D. in Economics from Johns Hopkins University. Prior to graduate study, Dr. Tomohara worked for the Japanese Ministry of Finance and National Tax Administration. A broad range of research skills, work experience, and contacts, earned Dr. Tomohara the distinction of being an economic consultant at the Urban Institute, the World Bank, and the Inter-American Development Bank. His experience includes economic research at Columbia University, and teaching as faculty at the City University of New York and University of Pittsburgh.

Molly Sherlock is a Ph.D. candidate in Economics at the Graduate Center of the City University of New York. Over the past three years, she has taught economics to undergraduate and master's students as a member of the faculty at Skidmore College, New York University, and the City University of New York. 


\section{ENDNOTES}

${ }^{1}$ Van Cayseele and Raynaerts (2007) use the case of Disneyland and an on-site McDonalds to investigate complementary platforms.

${ }^{2}$ Between 2000 and 2006, $20 \%$ of foreign visitors in the U.S. came from the U.K., while $18 \%$ came from Japan. Data on the source of foreign visitors was obtained from The U.S. Department of Commerce and the Japanese Ministry of Land, Infrastructure, and Transport.

${ }^{3}$ See (Bonham, Edmonds, and Mak, 2006) for an analysis of the impact of 9/11 on tourism within the United States.

${ }^{4}$ Recent work by Michael G. Vogt (2008) finds that the long-run income elasticity of demand for U.S. exports of tourism is 2.72. His analysis examines the demand for tourism services from the U.S. using Australia, Canada, Japan, Sweden, Switzerland, the U.K. and the Euro area to compute an index of world income using relative real GDP. Witt and Witt (1995) and Song and Li (2008) review the literature on forecasing tourism demand. Other important works include Durbarry (2008), Li, Wong, Song and Witt (2006), Li, Song and Witt (2006), Martin and Witt (1989), Petropoulos, Nikolopoulos, Patelis and Assimakopoulos (2005), Preez and Witt (2003), Wang (2008).

${ }^{5}$ The Ministry of Internal Affairs and Communications maintains data on the number of non-regular staff.

${ }^{6}$ In recent years China has been working to make it easier for foreign visitors to visit China. The increase in Japanese demand for tourism in China, and the relative decline in Japanese tourism in the United States, could also be viewed as an increase in the availability of substitutes. As China became a more available destination for international travel, demand for travel to the U.S. decreased.

\section{REFERENCES}

1. Bonham, Carl, Christopher Edmonds, and James Mak, 2006, The Impact of 9/11 and Other Terrible Global Events on Tourism in the United States and Hawaii, Journal of Travel Research 45(1), pp.99-110.

2. du Preez, Johann, Stephen F. Witt, 2003, Univariate versus multivariate time series forecasting: an application to international tourism demand, International Journal of Forecasting 19, pp. 435-451.

3. Durbarry, Ramesh, 2008, Tourism taxes: Implications for tourism demand in the U.K., Review of Development Economics 12(1), pp.21-36.

4. Li, Gang, Kevin K. F. Wong, Haiyan Song, and Stephen F. Witt, 2006, Time varying parameter and fixed parameter linear AIDS: An application to tourism demand forecasting, International Journal of Forecasting 22, pp.57-71.

5. Li, Gang, Haiyan Song, and Stephen F. Witt, 2006, Tourism demand forecasting: A time varying parameter error correction model, Journal of Travel Research 45, pp. 175-185.

6. Martin, Christine A. and Stephen F. Witt, 1989, Forecasting tourism demand: A comparison of the accuracy of several quantitative methods, International Journal of Forecasting, 5, pp. 7-19.

7. Petropoulos, C., K. Nikolopoulos, A. Patelis, and V. Assimakopoulos, 2005, A technical analysis approach to tourism demand forecasting, Applied Economics Letters (12), pp.327-333.

8. Song, Haiyan and Gang Li, 2008, Tourism demand modeling and forecasting-A review of recent research, Tourism Management 29, pp. 203-220.

9. Witt, Stephen F. and Christine A. Witt, 1995, Forecasting tourism demand: A review of empirical research, International Journal of Forecasting 11, pp. 447-475.

10. Wang, Yu-shan, 2009, The impact of crisis events and macroeconomic activity on Taiwan's international inbound tourism demand, Tourism Management, forthcoming.

11. Van Cayseele, Patrick and Jo Reynaerts, 2007, Complementary Platforms, LICOS Discussion Paper 186/2007.

12. Vogt, Michael G., 2008, Determinants of the demand for US exports and imports of tourism, Applied Economics, 40, pp.667-672. 


\section{NOTES}

